\title{
Implementasi Contextual Teaching and Learning dalam Pencapaian Perkembangan Aspek Agama pada Anak Usia Dini (Pendekatan Filsafat Ilmu-Ilmu Keislaman)
}

\author{
Armanila \\ Universitas Al Washliyah Medan \\ email: armanila88@gmail.com

\begin{tabular}{llll}
\hline Article received & $: 15$ Januari 2021 & Review process & $: 18$ Januari 2021 \\
Article accepted & $: 12$ Februari 2021 & Article published & $: 8$ Maret 2021 \\
\hline
\end{tabular}

\begin{abstract}
Abstrak
Beberapa praktik pembelajaran pada Pendidikan Anak Usia Dini (PAUD) disinyalir terjangkiti paham keagamaan yang radikal dan intoleran. Persoalan ini sejatinya merupakan masalah laten dalam pembelajaran agama di semua jenjang pendidikan, yakni pendekatan pembelajaran yang dogmatis dan doktriner. Karenanya artikel ini melakukan kajian tentang pendekatan pembelajaran dalam rangka pencapaian perkembangan aspek agama pada anak usia dini yang tidak dogmatis dan doktriner. Kajian ini fokus pada pendekatan contextual teaching and learning (CTL) berbasis kajian normativitas-historisitas dalam filsafat ilmu-ilmu keIslaman. Hasil kajian menemukan adanya benang merah filosofis antara pendekatan CTL dengan kajian normativitas-historisitas. Benang merah tersebut berupa historisitas Islam berbentuk pengalaman religius peserta didik, yang bersifat fleksibel dan temporer, yang dapat dijadikan sebagai konteks dalam pendekatan CTL . Pengalaman religius ini kemudian dieksplorasi dengan menggunakan pendekatan CTL sehingga menghasilkan makna bagi peserta didik.

Kata Kunci: anak usia dini; aspek perkembangan agama; contextual teaching and learning; kajian normativitas-historisitas
\end{abstract}

\section{Abstract}

Some learning practices in Early Childhood Education (PAUD) are allegedly infected with radical and intolerant religious understanding. This problem is actually a latent problem in religious learning at all levels of education, namely dogmatic and doctrinal approaches to learning. Therefore this article conducts a study on learning approaches in the context of achieving the development of aspects of religion in early childhood that are not dogmatic and doctrinaire. This study focuses on the contextual teaching and learning (CTL) approach based on normativity-historicity studies in the philosophy of Islamic sciences. The results of the study found a philosophical thread between the CTL approach and the normativity-historicity study. The common thread is in the form of Islamic historicity in the form of students' religious experiences, which are flexible and temporary, which can be used as a context in the CTL approach. This religious experience is then explored using the CTL approach so as to produce meaning for students.

Keywords: aspects of religious development; contextual teaching and learning; early childhood; the study of normativity-historicity

Implementasi Contextual Teaching and Learning dalam Pencapaian Perkembangan Aspek Agama pada Anak Usia Dini (Pendekatan Filsafat Ilmu-Ilmu Keislaman) Copyright (c) 2021 Armanila 


\section{A. PENDAHULUAN}

Perkembangan menuju pada proses ke arah yang lebih sempurna dan tidak begitu saja dapat di ulang kembali. Oleh karena itu, kualitas perkembangan anak di masa depannya, sangat ditentukan oleh stimulasi yang diperolehnya sejak dini. Pemberian stimulasi pendidikan adalah hal yang sangat penting. Bentuk stimulasi yang diberikan harusnya dengan cara yang tepat sesuai dengan tingkat perkembangannya, salah satu bentuk stimulasinya adalah Bahasa.

Beberapa waktu terakhir ini, pembelajaran Pendidikan Agama Islam (PAI) dipersepsikan lebih dekat dengan cara pandang keagamaan yang radikal dan perilaku intoleran. Salah satunyasurvei yang dilakukan Pusat Pengkajian Islam dan Masyarakat (PPIM) Universitas Islam Negeri (UIN) Syarif Hidayatullah Jakarta pada tahun 2017, sebagaimana dikutip dalam fakta.news (18/05/2018) mencatat tentang tingginya tingkat intoleransi pada mahasiswa/siswa sekolah beragama Islam. Terdapat 51,1 persen responden mahasiswa/siswa beragama Islam yang memiliki opini intoleran terhadap aliran Islam minoritas. Aliran ini dipersepsikan berbeda dari mayoritas, seperti Ahmadiyah dan Syiah. Sementara 34,3 persen responden yang sama tercatat memiliki opini intolerans kepada kelompok agama lain selain Islam.

Beberapa fakta tentang radikalisme dan intoleransi ini pernah muncul dalam praktik pengelolaan pendidikan anak usia dini. Misalnya lagu "tepuk anak saleh" yang pernah dipersoalkan karena memuat kalimat "Islam yes, kafir no". Kalimat ini dianggap mengandung nilai intoleran terhadap orang yang berbeda keyakinan. Polemik selesai sewaktu Menteri Pendidikan Nasional (Mendiknas) Muhadjir Efendi, sebagaimana dikutip info.kemdikbud.web.id, menyatakan bahwa kalimat tersebut ditujukan untuk diri peserta didik masing-masing agar menguatkan keimanannya, tidak ditujukan untuk melabeli orang lain yang berbeda keyakinan dengan sebutan kafir.

Namun fakta lain menunjukkan pemahaman yang berbeda. Dalam kasus yang berbeda, BBC.com mewawancarai sejumlah orang tua tentang pemahaman anak mereka tentang kata "kafir". Mereka menyampaikan bahwa anak-anak mereka memahami kata "kafir" sebagai orang yang tidak beragama Islam. Artinya faktanya berbeda dengan yang

Implementasi Contextual Teaching and Learning dalam Pencapaian Perkembangan Aspek Agama pada Anak Usia Dini (Pendekatan Filsafat Ilmu-Ilmu Keislaman) Copyright (c) 2021 Armanila 
http://jurnaltarbiyah.uinsu.ac.id/index.php/raudhah

e-mail: jurnalraudhah@uinsu.ac.id

p-ISSN: 2338-2163

e-ISSN: $2716-2435$

disampaikan oleh Mendikbud. Dalam kasus ini kata "kafir" tidak digunakan untuk menunjuk keberagamaan masing-masing, melainkan untuk memberi label kepada keagamaan seseorang yang berbeda dengan dirinya.

Mempersepsikan orang lain dengan cara seperti ini dapat menimbulkan disintegrasi sosial. Masing-masing kelompok akan menilai dan memandang kelompok lain dengan penuh prasangka. Secara sosio-historis hubungan yang dibangun berdasarkan konsep “iman versus kafir" adalah hubungan pertentangan, perpecahan, dan permusuhan. Jika konsep ini masuk dalam PAUD apalagi sengaja ditanamkan dan diinternalisasikan dalam diri peserta didik, dapat berakibat lahirnya nilai-nilai intoleran kepada orang lain yang berbeda keyakinan di usia yang masih sangat dini.

Agar peserta didik pada PAUD terbebas dari beberapa pembelajaran yang terindikasi radikal dan intoleran, perlu dikembangkan pendekatan yang tidak dogmatis dan doktriner.Perlu ada pendekatan alternatif yang mampu mengembangkan dimensi-dimensi religiusitas anak tanpa dogma dan doktrin. Hal ini bisa dilakukan dengan pendekatan yang mengarahkan peserta didik untuk menemukan makna tentang keberagamaan dari kehidupan keseharian mereka, baik konteks pribadi, sosial maupun budaya. Pendekatan ini dikenal dengan istilahcontextual learning and teaching (CTL) atau pembelajaran kontekstual.

Dalam kajian studi Islam, filsafat ilmu-ilmu keislaman juga memiliki semangat yang sejalan dengan dedogmatisasi-deindoktrinasi ini, yakni melalui pemahaman Islam kontekstual. Seperti gagasan Fazlur Rahman tentang teori penafsiran gerak ganda, Abdullah Saeed tentang penafsiran kontekstual, dan Muhammad Syahrur tentang pemahaman Islam kontemporer. Oleh karena itu semangat pembelajaran yang tidak dogmatis dan doktriner melalui CTL perlu dipertemukan dengan gagasan-gagasan filsafat ilmu keislaman dalam rangka mengembangkan model pembelajaran Islam kontemporer dan kontekstual, khususnya dalam mencapai perkembangan aspek agama pada diri anak usia dini.

Berdasarkan latar belakang masalah tersebut, disusunlah rumusan masalah pada kajian ini, yaitu; 1) Mengapa pendekatan CTL dijadikan sebagai alternatif dalam pencapaian perkembangan aspek agama pada PAUD yang terbebas dari indikasi 
http://jurnaltarbiyah.uinsu.ac.id/index.php/raudhah

e-mail: jurnalraudhah@uinsu.ac.id

p-ISSN: 2338-2163

e-ISSN: 2716-2435

pemahamanradikal dan intoleran? 2) Bagaimanakah CTL dalam perspektif Pendidikan Islam? 3) Bagaimana CTL dan gagasan Islam kontemporer bisa memfasilitasi perkembangan agama pada anak usia dini tanpa pendekatan doktrin dan dogma? 4) Bagaimana mengimplementasikan pendekatan CTL berbasis gagasan Islam kontemporer dalam mencapai perkembangan dimensi religius pada anak usia dini?

Kajian tentang CTL dalam pembelajaran sudah banyak dilakukan oleh para akademisi. Namun kebanyakan riset tentang CTL dilakukan pada pembelajaran non PAI. Tidak banyak riset CTL yang dilakukan terhadap mata pelajaram PAI. Salah satu dari yang tidak banyak itu dilakukan oleh (Abdi, 2011) yang menyatakan bahwa pendekatan CTL dalam pembelajaran PAI lebih dapat menyentuh aspek afeksi serta dapat memotivasi peserta didik dalam mengaktualisasikan nilai-nilai atau konsep-konsep yang didapatkan dari materi PAI. Penelitian yang senada juga dilakukan oleh (Harudin, 2018) yang menjadikan tari Musekat dan tari Saman sebagai sumber belajar, yaitu dengan melakukan penggalian terhadap nilai-nilai pada tarian-tarian tersebut. Hasil riset menunjukkan adanya peningkatan hasil belajar PAI. Perbedaan keduanya yaitu, penelitian Harudin menjadikan kearifan lokal sebagai sumber pembelajaran kontekstual sedangkan penelitian Abdi tidak.

Kajian yang dilakukan penulis lebih bersifat filosofis. Penulis menghubungkan teori kontekstual dalam CTL dengan pendekatan kontekstual dalam studi Islam. Menurut (Hanafi, 2017) usaha semacam ini sudah diterapkan dalam kurikulum PAI di perguruan tinggi umum (PTU) pada era kurikulum tahun 2002. Era kurikulum 2002 sudah memasukkan banyak kajian Islam kontemporer dalam konten kurikulum PAI di PTU, seperti hak asasi manusia, demokrasi, sistem hukum dan politik, masyarakat madani serta toleransi. Pendekatan pembelajaran sudah bersifat multidisiplin dan tidak lagi monodisiplin seperti pada kurikulum-kurikulum sebelumya.

Meskipun demikian, Hanafi hanya melakukan riset produk kurikulum. Sementara artikel ini disusun dengan pendekatan filosofis guna menemukan landasan filosofis pengembangan kurikulum PAI pendekatan CTL berbasis pemahaman Islam kontemporer. Di samping itu, studi ini juga lebih pada pembelajaran jenjang PAUD. Penekanan ini penting dikarenakan usia PAUD merupakan usia emas. Pemahaman yang didapatkan pada usia dini akan menjadi pondasi pemahaman keagamaan pada usia-usia selanjutnya.

Implementasi Contextual Teaching and Learning dalam Pencapaian Perkembangan Aspek Agama pada Anak Usia Dini (Pendekatan Filsafat Ilmu-Ilmu Keislaman) Copyright (c) 2021 Armanila 


\section{B. METODE PENELITIAN}

Metode yang digunakan adalah library risearch. Menurut (Mestika, 2008) metode ini merupakan serangkaian kegiatan dengan metode pengumpulan data pustaka, membaca, serta mengelola bahan penelitian. Selanjutnya (Mahmud, 2011) menambahkan bahwa penelitian kepustakaan yakni jenis penelitian yang dilakukan dengan cara membaca bukubuku atau majalah atau sumber data lainnya untuk menghimpun data dari berbagai literatur, baik perpustakaan maupun di tempat-tempat lain. Dengan demikian, penelitian ini dilakukan dengan mengumpulkan bukti-bukti tertulis baik dar buku-buku, jurnal, artikel yang berkaitan dengan model yang akan di analisis.

Analisis data yang digunakan adalah content analysis, yang catata penelitiannya diambil dari menelaah entitas isi catatan bahan bacaan pustaka yang pembahasannya bersifat mendalam. Analisis ini digunakan untuk data kualitatif. Penelitian kualitatif deskriptif yaitu penelitian yang digunakan untuk mendeskripsikan dan menganalisis fenomena, aktivitas sosial, sikap, kepercayaan, persepsi, pemikiran orang secara individual maupun kelompok.

\section{HASIL TEMUAN DAN PEMBAHASAN}

\section{Menemukan Makna Melampaui Doktrin dan Dogma}

Menurut (Johnson, 2008), Contextual Teaching and Learning (CTL) sebagai sebuah sistem yang merangsang otak untuk menyusun pola-pola yang mewujudkan makna. Pembelajaran CTL mampu menghasilkan makna dengan menghubungkan muatan akademis dengan konteks dari kehidupan sehari-hari. Dengan memanfaatkan kenyataan bahwa lingkungan merangsang sel-sel saraf otak untuk membentuk jalan, sistem ini memfokuskan diri pada konteks atau hubungan-hubungan. Pendekatan CTL mulai berkembang di Amerika sewaktu muncul kesadaran tentang adanya dikotomi pendidikan. Dikotomi yang dimaksudkan adalah adanya dualisme antara pendidikan diploma, yang peserta didiknya dibekali dengan pengetahuan dan keterampilan teknis, dengan pendidikan sarjana, yang peserta didiknya hanya dibekali dengan gagasan-gagasan, konsep, pengetahuan itu sendiri, dan kumpulan informasi.

Implementasi Contextual Teaching and Learning dalam Pencapaian Perkembangan Aspek Agama pada Anak Usia Dini (Pendekatan Filsafat Ilmu-Ilmu Keislaman) Copyright (c) 2021 Armanila 
http://jurnaltarbiyah.uinsu.ac.id/index.php/raudhah

e-mail: jurnalraudhah@uinsu.ac.id

p-ISSN: 2338-2163

e-ISSN: $2716-2435$

Para praktisi pendidikan di Amerika menilai bahwa pendidikan diploma lebih berhasil mendidik peserta didik. Ini dikarenakan pembelajaran pada program diploma tidak hanya membahas tentang gagasan, konsep, pengetahuan, dan kumpulan informasi melainkan ada keterampilan lain yang dilatihkan kepada peserta didik. Keterampilan tersebut berupa sesuatu yang bersifat kontekstual, yakni sesuai dengan konteks materi yang dipelajari. Karena itulah kemudian dikembangkan pendekatan kontekstual dalam pembelajaran materi akademik. Strategi utamanya adalah menerapkan muatan akademis ke dalam situasi dunia nyata. Tujuannya adalah agar peserta didik mampu menemukan makna yang muncul dari hubungan antara materi akademik dengan konteks yang disajikan dalam pembelajaran. Johnson mengartikan makna dengan arti penting dari sesuatu. Dengan demikian makna yang dimaksudkan adalah arti penting materi peralajaran yang dipelajari bagi diri peserta didik.

Keberhasilan pembelajaran tidak diukur dari banyaknya materi akademis yang dihafalkan oleh peserta didik, melainkan adanya makna yang berhasil ditemukan. Semakin mampu mengaitkan materi akademis dengan konteks, peserta didik akan semakin banyak mendapatkan makna. Semakin banyak keterkaitan yang ditemukan siswa dalam suatu konteks yang luas, pembelajaran menjadi semakin bermakna bagi mereka. Kemampuan menguasai makna akan menuntun mereka untuk memahami pengetahuan dan keterampilan yang dipelajari.

Dengan demikian, keberhasilan pembelajaran pendidikan agama sejatinya bukan seberapa banyak doktrin dan dogma yang dihafalkan oleh peserta didik. Keberhasilan itu diukur dari kemampuan dalam menghubungkan materi agama dengan konteks kehidupan sehari-hari dan kemampuan memproduksi makna dari hubungan tersebut.Misalnya makna berdoa bagi seorang anak usia dini, makna menjalankan ibadah salat, makna belajar mengenal agama-agama yang berbeda, makna belajar hari-hari besar agama yang berbeda, dan lain sebagainya.

Pendekatan CTL mensyaratkan beberapa hal agar peserta didik dapat menemukan makna dalam kegiatan pembelajaran. (Alwasilah, 2008) mengidentifikasi ada tujuh strategi yang mesti ditempuh agar pebelajaran CTL berhasil mencapai tujuan. Tujuh strategi tersebut adalah: (1) pengajaran berbasis masalah (problem based learning; (2)

Implementasi Contextual Teaching and Learning dalam Pencapaian Perkembangan Aspek Agama pada Anak Usia Dini (Pendekatan Filsafat Ilmu-Ilmu Keislaman) Copyright (c) 2021 Armanila 
http://jurnaltarbiyah.uinsu.ac.id/index.php/raudhah

e-mail: jurnalraudhah@uinsu.ac.id

p-ISSN: 2338-2163

e-ISSN: $2716-2435$

menggunakan konteks yang beraga; (3) mempertimbangkan kebhinekaan peserta didik;

(4) memberdayakan peserta didik untuk belajar mandiri; (5) belajar berkolaborasi; (6) menggunakan penilaian autentik; dan (7) mengejar standar tinggi.

\section{Contextual Teaching and Learning (CTL) dalam Perspektif Pendidikan Islam}

Perkembangan dunia Islam mencatat bahwa CTL merupakan salah satu metode pembelajaran yang bersifat produktif. Jika yang dimaksudkan dengan CTL adalah kontekstualisasi, maka metode ini sebenarnya telah diterapkan oleh Rasulullah saw saat menerima wahyu pertama dalam sejarah perkembangan dakwah Islam. Saat itu kontekstualisasi dapat dilihat dari praktik-praktik Rasulullah saw sebagai berikut: Pertama, Rasulullah saw menyampaikan pembelajaran secara berangsur-angsur. Rasulullah saw tidak menyampaikan hadis (materi pendidikan) secara beruntun, melainkan sedikit demi sedikit agar dapat meresap dalam hati”. Penyampaian secara berangsur-angsur, mudah untuk dipahami, dihafal dan amalkan. Seperti dalam menanamkan aqidah yang benar, melaksanakan ibadah, hukum, adat yang tinggi, akhlak yang utama serta memperkokoh iman dan kesabaran secara berangsur-angsur.(Khotib, 1981)

Sebagaimana firman Allah swt dalam Quran Surah Al-Alaq ayat 1-5 yang artinya: "Bacalah dengan (menyebut) nama Tuhanmu yang Menciptakan, Dia telah menciptakan manusia dari segumpal darah, bacalah, dan Tuhanmulah yang Maha pemurah, yang mengajar (manusia) dengan perantaran kalam, Dia mengajar kepada manusia apa yang tidak diketahuinya”.(Al-Qur'an, 2014)

Ayat di atas, mejelaskan bahwa sesungguhnya pertama kali Islam datang dengan menyampaikan pesan membaca, yang tersirat di dalam wahyu pertama yang dibawa oleh malaikat Jibril kepada Rasulullah Saw. Artinya, perintah tersebut bukan hanya sekedar mendengar atau melihat. Namun, jika dikaitkan dengan proses belajar mengajar dengan baca dan tulis yaitu kedudukannya untuk mengetahui hal-hal yang belum diketahui. Dengan demikian, telah terjadi proses "mengkonstruksi pengetahuan" melalui keterlibatan aktif dalam proses pembelajaran. Oleh karena itu, konsep ini menjadi dasar dalam penerapan komponen CTL pada komponen contruktivism, dimana hal ini dapat dicermati 
http://jurnaltarbiyah.uinsu.ac.id/index.php/raudhah

e-mail: jurnalraudhah@uinsu.ac.id

p-ISSN: 2338-2163

e-ISSN: $2716-2435$

yaitu ketika pengetahuan tersebut, dibangun oleh manusia sedikit demi sedikit. Selain itu, pada materi pendidikan Islam lebih didominasi oleh ilmu amaliah, sehingga koteks ilmu dengan amal sehari-hari juga dominan atau diterapkan dalam kehidupan nyata. Misalnya ketika Rasulullah saw memerintahkan untuk belajar memanah, berkuda dan berenang. Karena materi tersebut sangat kontekstual dengan kebutuhan pada saat itu, dalam memenangkan peperangan bagi kaum Muslimin.

Kedua, implementasi atau penerapan ilmu. Pada dasarnya Rasulullah saw telah mengajari sahabat sampai mereka paham akan maknanya, hukumnya serta sampai kepada implikasi mengenai hukum tersebut. Artinya bahwa para sahabat langsung melihat dan mengetahui dari Rasulullah saw, yang kemudian dipraktekkan. Dengan demikian, komponen CTL pada inquiry (menemukan) dengan proses observasi, bertanya, mengajukan dugaan, mengumpulkan data dan menyimpulkan, telah dilakukan oleh para sahabat dalam proses belajar mengajar dengan Rosulullah saw. Dan metode ini, terus dibudayakan pada pondok-pondok pesantren sejak masih tradisional hingga ke modern.

Ketiga, bervariasi dan memperhatikan tingkatan yang berbeda-beda. Rasulullah saw sangat memperhatikan tingkatan yang berbeda-beda, serta kondisi para sahabat. Oleh sebab itu, dalam penyampaian materi Rasulullah selalu menggunakan cara yang bervariasi. Jika tidak, maka dalam pengajaran dan pengarahan dapat menimbulkan kebosanan dalam jiwa dan berdampak menjadi kecil daya gunanya. Hal Ini menunjukkan bahwa perbedaan kemampuan dalam kecerdasan atau intelegensi harus menjadi perhatian serta pertimbangan dalam pelaksanaan belajar mengajar. Setelah belajar dari Rasulullah, kemudian mengkaji isinya, ilmunya dan pengamalannya secara bersama-sama (berdiskusi). Kemudian, pengajaran Rasulullah saw tidak tergantung pada tempat yang terbatas dan kesempatan tertentu, jika beliau ditanya atau dimintai fatwa di jalan, beliaupun memberi jawaban dan solusi dan dalam kesempatan apasaja yang memungkinkan. Sebagaimana firman Allah swt dalam Quran Surah An-Nahl ayat 43, yang artinya: "Dan Kami tidak mengutus sebelum kamu, kecuali orang-orang lelaki yang Kami beri wahyu kepada mereka; Maka bertanyalah kepada orang yang mempunyai pengetahuan, jika kamu tidak mengetahui’.(Al-Qur’an, 2014)

Implementasi Contextual Teaching and Learning dalam Pencapaian Perkembangan Aspek Agama pada Anak Usia Dini (Pendekatan Filsafat Ilmu-Ilmu Keislaman) Copyright (c) 2021 Armanila 
http://jurnaltarbiyah.uinsu.ac.id/index.php/raudhah

e-mail: jurnalraudhah@uinsu.ac.id

p-ISSN: 2338-2163

e-ISSN: $2716-2435$

Dalam konteks pembelajaran modern dapat dikatakan bahwa Rasulullah saw menggunakan pendekatan CTL pada kasus tersebut pada komponen questioning (bertanya). Hal tersebut terlihat ketika bertanya dari para sahabat pada Rasul, dari Rasul pada sahabat dan dari sahabat pada sahabat yang lain, termasuk di dalam kegiatan diskusi. Sebagaimana yang ditegaskan oleh ayat di atas, bahwa dalam proses belajar mengajar harus ada proses atau pendekatan saling bertanya (questioning).

Keempat, mengadakan majelis-majelis pengajaran. Semua majlis-majlis Rasulullah Saw adalah majlis ilmu. Rasulullah saw menentukan waktu-waktu tertentu untuk mengajari sahabat. Mereka sangat ingin menghadiri majlis tersebut dengan sepenuh kemampuan dan perhatian. Bahkan beberapa sahabat ada yang bergiliran dengan temannya untuk mengikuti majlis ta'lim Rasulullah saw dan menyampaikan hasilnya dari belajar itu kepada sahabat yang diajak bergiliran karena harus bekerja mencari ma'isyah. Karena selalu mempelajari terhadap apa saja yang dipelajari dari Rasulullah Saw. Sampai mereka meresapi dan hafal. Kondisi tersebut sebagaimana firman Allah swt dalam Quran Surah Ali Imron ayat 159, yang berbunyi: "Maka disebabkan rahmat dari Allah-lah kamu berlaku lemah lembut terhadap mereka. Sekiranya kamu bersikap keras lagi berhati kasar, tentulah mereka menjauhkan diri dari sekelilingmu. Karena itu ma'afkanlah mereka, mohonkanlah ampun bagi mereka, dan bermusyawaratlah dengan mereka dalam urusan itu. Kemudian apabila kamu telah membulatkan tekad, maka bertawakkallah kepada Allah. Sesungguhnya Allah menyukai orang-orang yang bertawakkal kepada-Nya".(AlQur'an, 2014)

Dengan demikian, penjelasan di atas menunjukkan bahwa metode pembelajaran CTL pada komponen learning community (mayarakat belajar) telah diterapkan oleh Rasulullah saw, kemudian lebih dikembangkan dan ditingkatkan pada proses pendidikan dan pelajaran hingga saat ini. Dalam leaning community, pembelajaran dilaksanakan dalam kelompok-kelompok belajar, agar materi dimusyawarahkan dan dibahas bersama, artinya dalam memberi pelajaran hendaklah bermusyawarah tentang masalah keduniaan seperti ekonomi, politik, pendidikan dll.

Implementasi Contextual Teaching and Learning dalam Pencapaian Perkembangan Aspek Agama pada Anak Usia Dini (Pendekatan Filsafat Ilmu-Ilmu Keislaman) Copyright (c) 2021 Armanila 
http://jurnaltarbiyah.uinsu.ac.id/index.php/raudhah

e-mail: jurnalraudhah@uinsu.ac.id

p-ISSN: 2338-2163

e-ISSN: $2716-2435$

Kelima, keteladanan Rasulullah saw. Misalnya keteladanan Rasulullah sewaktu mengajardan menguasai materi tentang salat, puasa, haji, bepergian, muamalah, perjalanan hidupnya dan lain-lain. Rasulullah saw menyampaikan melalui pemodelan keteladanan maupun peristiwa-peristiwa dan kejadian-kejadian yang disaksikan oleh para sahabat. Dengan demikian, hal ini menunjukkan bahwa Rasulullah Saw melakukan pendidikan dan pengajaran Islam dengan metode pembelajaran CTL pada komponen modeling (pemodelan). Dan memang Rasulullah Saw dijadikan model oleh Allah untuk mendidik manusia, sebagaimana firman Allah swt dalam Quran Surah Al-Ahzab ayat 21, yang artinya: "Sesungguhnya telah ada pada (diri) Rasulullah itu suri teladan yang baikbagimu (yaitu) bagi orang yang mengharap (rahmat) Allah dan (kedatangan) hari kiamat dan Dia banyak menyebut Allah".(Al-Qur'an, 2014)

Ayat ini, menjelaskan bahwa yang menjadi model adalah Rasulullah saw. Selain beliau juga ada model-model yang lain yaitu para sahabat seperti Abu bakar, Umar, Ustman, Ali.

Keenam, peristiwa-peristiwa yang terjadi pada diri Rasulullah saw dan dikalangan umat Islam. Ketika terjadi peristiwa tertentu pada diri Rasulullah saw dan dikalangan umat Islam, para sahabat bertanya pada Rasulullah saw, tentang hukum dari peristiwaperistiwa tersebut. Kemudian, Rasulullah saw memberi fatwa dan menjawab sejelasjelasnya tentang hukum yang mereka tanyakan dan para sahabat menanggapinya dengan cara melaksanakan fatwa tersebut. Hal ini menunjukkan adanya praktik CTL pada komponen reflection (refleksi) dalam proses pembelajaran refleksi. Ini terjadi dikalangan para sahabat setelah mendapatkan materi pelajaran (al-Qur'an dan hadis) dari Rasulullah saw dengan mendiskusikan materi tersebut dan menerapkanya dalam kehidupan seharihari. Pada hakikatnya reflaction (refleksi) merupakan respon terhadap kejadian, aktivitas atau pengetahuan yang baru di terima sebagaimana tersebut di atas. Para sahabat membuat hubungan-hubungan antara pengetahuan yang dimiliki sebelumnya dengan pengetahuan yang baru untuk di amalkan atau dipraktekkan. Sebagaimana firman Allah swt dalam Quran Surah Al-Hasyr ayat 18, yang artinya: "Hai orang-orang yang beriman, bertakwalah kepada Allah dan hendaklah setiap diri memperhatikan apa yang telah

Implementasi Contextual Teaching and Learning dalam Pencapaian Perkembangan Aspek Agama pada Anak Usia Dini (Pendekatan Filsafat Ilmu-Ilmu Keislaman) Copyright (c) 2021 Armanila 
http://jurnaltarbiyah.uinsu.ac.id/index.php/raudhah

e-mail: jurnalraudhah@uinsu.ac.id

p-ISSN: 2338-2163

e-ISSN: 2716-2435

diperbuatnya untuk hari esok (akhirat); dan bertakwalah kepada Allah, sesungguhnya Allah Maha mengetahui apa yang kamu kerjakan”. (Al-Qur’an, 2014)

Ketujuh, evaluasi. Proses pendidikan dan pengajaran Rasulullah saw selalu memperhatikan kecakapan, perilaku dan kehidupan para sahabat, dari hasil pantauan ini Rasulullah saw mengetahui secara persis para sahabat yang kuat atau lemah hafalanya, yang cerdas atau lambat daya fikirnya sehingga Rasulullah saw dapat menyesuaikan tingkat pelajaranya kepada sahabat yang berbeda-beda itu. Misalnya dalam penulisan hadis Abu sa'id berkata,"kami mohon izin kepada Rasul untuk menulis hadis, tetapi beliau tidak mengizinkan kami." Namun di sisi lain diriwayatkan dari Rofii bin Khodji bahwa ia berkata, "Kami bertanya, wahai Rasulullah saw, kami mendengar sesuatu dari engkau, apakah saya boleh menulisnya? Beliau menjawab "tulislah dan tidak dosa". Dalam kasus ini Rasulullah saw melarang untuk menulis hadis pada orang yang kuat hafalanya khawatir ada ketergantungan pada tulisan, sedangkan membolehkan untuk menulisnya pada orang yang lemah hafalanya. Fenomena tersebut, menunjukkan bahwa Rasulullah Saw telah melaksanakan CTL pada komponen authentic assessment (penilaian yang sebenarnya) penilaian dilaksanakan selama proses belajar dan sesudahnya berkesinambungan dan terintegrasi. Sebagaimana firman Allah swt dalam Quran Surah Al-Baqarah ayat 284, yang artinya: "Kepunyaan Allah-lah segala apa yang ada di langit dan apa yang ada di bumi. dan jika kamu melahirkan apa yang ada di dalam hatimu atau kamu menyembunyikan, niscaya Allah akan membuat perhitungan dengan kamu tentang perbuatanmu itu. Maka Allah mengampuni siapa yang dikehandaki-Nya dan menyiksa siapa yang dikehendaki-Nya; dan Allah Maha Kuasa atas segala sesuatu”. (Al-Qur'an, 2014)

Dengan demikian, penilaian Allah swt bukan hanya lahiriyah atau yang tampak atau yang bisa dilihat indikatornya saja, tetapi menyangkut aspek batiniyah, hal yang tersembunyi, hal yang tidak bisa dilihat oleh mata manusia, tidak bisa didengar oleh telinga manusia, tidak bisa dicium oleh hidung manusia, ini menunjukkan authentic assessment.

Implementasi Contextual Teaching and Learning dalam Pencapaian Perkembangan Aspek Agama pada Anak Usia Dini (Pendekatan Filsafat Ilmu-Ilmu Keislaman) Copyright (c) 2021 Armanila 
http://jurnaltarbiyah.uinsu.ac.id/index.php/raudhah

e-mail: jurnalraudhah@uinsu.ac.id

p-ISSN: 2338-2163

e-ISSN: $2716-2435$

\section{Normativitas-historisitas Sebagai Pendekatan dalam Pembelajaran CTL}

Pendapat (Abdullah, 2002) bahwa wacana studi agama kontemporer tidak dapat hanya dilihat dari sudut pandang normativitas ajaran wahyu belaka. Meskipun sudut pandang ini merupakan ciri khas studi agama, tapi agama juga harus dilihat dari sudut historisitas pemahaman dan interpretasi orang per orang atau kelompok-kelompok terhadap norma-norma ajaran agama yang dipeluknya. Selama ini hubungan antara normativitas dan historisitas agama tampak kaku dan tegang. Pada umumnya normativitas ajaran wahyu ditelaah dengan pendekatan doktrinal teologis. Sementara historisitas keberagamaan manusia ditelaah lewat berbagai sudut pendekatan keilmuan sosialkeagamaan yang bersifat multi dan interdisipliner. Bagi Amin Abdullah pendekatan yang dikotomik seperti ini harus diakhiri. Hubungan antara keduanya tidak harus mengambil posisi berhadap-hadapan, tetapi menyatu dalam satu dalam satu keutuhan yang kokoh dan kompak. Makna terdalam dan moralitas keagamaan tetap ada, tetapi begitu makna dan moralitas keagamaan tadi memasuki wilayah historitas kehidupan sehari-hari manusia, maka ia otomatis tidak bisa dihindarkan dari jebakan ruang dan waktu.

Fazlur Rahman dalam (Abdullah, 2012) menjelaskan bahwa Islam normatif hanyalah al-Qur'an dan hadis nabi. Sementara seluruh komponen ilmu-ilmu keislaman, khususnya kalam, tafsir, hadis, fikih, filsafat, tasawuh, dan akhlak masuk dalam kawasan Islam historis. Bangunan pengetahuan pada ilmu-ilmu keislaman ini dirintis dan diformulasikan oleh manusia-manusia yang hidup pada masa tertentu, dan dipengaruhi oleh masalah-masalah dan tantangan-tantangan yang sesuai dengan konteks waktu saat itu. Dengan demikian konstruksi pengetahuan yang dihasilkan menjadi selalu terbuka untuk dikaji ulang.

Pendekatan CTL dalam mencapai perkembangan aspek agama pada anak usia dini bisa diarahkan kepada sisi historisitas Islam yang bersifat fleksibel dan temporer. Dengan demikian peserta didik tidak belajar doktrin dan dogma agama. Adapun yang dipelajari adalah pengalaman keagamaan (religious experience), baik pengalaman diri sendiri maupun orang lain, baik yang sedang terjadi maupun yang sudah menyejarah. Meskipun pengalaman keagamaan memiliki dimensi yang luas, dikarenakan konteks kajian ini

Implementasi Contextual Teaching and Learning dalam Pencapaian Perkembangan Aspek Agama pada Anak Usia Dini (Pendekatan Filsafat Ilmu-Ilmu Keislaman) Copyright (c) 2021 Armanila 
http://jurnaltarbiyah.uinsu.ac.id/index.php/raudhah

e-mail: jurnalraudhah@uinsu.ac.id

p-ISSN: 2338-2163

e-ISSN: $2716-2435$

adalah CTL, maka pengalaman yang dialami langsung oleh peserta didik lebih diutamakan.

\section{Pembelajaran CTL Berbasis Islam Kontemporer Pada AUD}

Menurut (Pearce et al., 2017) terdapat lima dimensi religiusitas dalam diri seseorang, yaitu dimensi keyakinan (beliefs), eksklusivitas (exlucivity), praktik eksternal (esternal practice), ibadah pribadi (internal practice), dan arti penting agama (Religious Salience). Dimensi keyakinan terdiri dari keyakinan terhadap kehidupan setelah kematian, keyakinan terhadap Tuhan, malaikat, setan, hari pembalasan dan lain-lain. Dimensi eksklusivitas berupa konversi agama, hanya mempraktikkan satu agama saya, pandangan tentang kebenaran, dan kebebasan untuk memilih agama. Adapun dimensi praktik eksternal meliputi kehadiran di tempat ibadah, berdoa untuk kedua orang tua, kelompok agama, dan kesetiaan berbagi. Sementara dimensi ibadah pribadimeliputi frekuensi doa, baca kitab, dan puasa. Sedangkan dimensi srti penting agama meliputi kajian tentang pentingnya iman, bagaimana memutuskan, dan komitmen terhadap Tuhan.

Sebagaimana dijelaskan sebelumnya bahwa CTL bertujuan agar peserta didik dapat menemukan makna di balik materi yang dipelajari. Pada lima dimensi yang sudah diuraikan konteks makna tersebut dapat ditemukan pada dimensi kelima, arti penting agama. Dengan demikian dapat dikatakan bahwa tujuan pendekatan CTL pada pencapaian perkembangan aspek agama pada anak usia dini adalah agar peserta didik dapat menemukan arti penting agama bagi diri mereka. Agar dapat menemukan arti penting agama, maka peserta didik harus menghubungkan materi pelajaran dengan kehidupan yang mereka hadap sehari-hari.

Telah dijelaskan sebelumnya bahwa pencapaian perkembangan aspek agama pada anak usia dini tidak dilakukan dengan mengajarkan doktrin dan dogma, melainkan mengeksplorasi pengalaman keagamaan peserta didik. Bersumber dari pengalaman keagamaan ini, peserta didik dapat diarahkan untuk mengonstruksi pengetahuan mereka tentang keberagamaan yang bermakna bagi diri mereka. Implementasi konsep ini dapat dilihat pada tabel 1 sedangkan standar isi dalam Permendikbud 146 Tahun 2014 disajikan pada tabel 2:

Implementasi Contextual Teaching and Learning dalam Pencapaian Perkembangan Aspek Agama pada Anak Usia Dini (Pendekatan Filsafat Ilmu-Ilmu Keislaman) Copyright (c) 2021 Armanila 
Tabel 1. Implementasi Konsep untuk Perkembangan Aspek Agama

\begin{tabular}{|c|c|c|}
\hline Kompetensi Dasar & Usia & Indikator Pencapaian Perkembangan AUD \\
\hline \multirow{7}{*}{$\begin{array}{l}\text { 3.1. Mengenal kegiatan } \\
\text { beribadah sehari-hari } \\
\text { 4.1. Melakukan kegiatan } \\
\text { beribadah sehari-hari } \\
\text { dengan tuntunan } \\
\text { orang dewasa }\end{array}$} & $0-1$ tahun & Bersentuhan dengan kegiatan religius \\
\hline & $1-2$ tahun & Terlibat dalam kegiatan religius \\
\hline & 2-3 tahun & $\begin{array}{l}\text { Mengidentifikasi kegiatan yang bernilai religius } \\
\text { dalam kehidupan sehari-hari }\end{array}$ \\
\hline & 3-4 tahun & $\begin{array}{l}\text { Membedakan kegiatan yang bernilai religius } \\
\text { dengan non-religius dalam aktivitas sehari-hari }\end{array}$ \\
\hline & 4-5 tahun & $\begin{array}{l}\text { Menilai arti penting dimensi ibadah pribadi } \\
\text { dalam diri peserta didik }\end{array}$ \\
\hline & $5-6$ tahun & $\begin{array}{l}\text { Menilai arti penting dimensi praktik eksternal } \\
\text { dalam diri peserta didik }\end{array}$ \\
\hline & & $\begin{array}{l}\text { Menilai realitas adanya perbedaan cara } \\
\text { beribadah dan beragama dalam masyarakat }\end{array}$ \\
\hline
\end{tabular}

Tabel 2. Perkembangan Aspek Agama Berdasarkan Permendikbud 146 Tahun 2014

\begin{tabular}{|c|c|c|}
\hline Kompetensi Dasar & Usia & Indikator Pencapaian Perkembangan AUD \\
\hline \multirow[t]{5}{*}{$\begin{array}{l}\text { 3.1. Mengenal kegiatan } \\
\text { beribadah sehari-hari } \\
\text { 4.1. Melakukan kegiatan } \\
\text { beribadah sehari-hari } \\
\text { dengan tuntunan } \\
\text { orang dewasa }\end{array}$} & $0-1$ tahun & $\begin{array}{l}\text { Anak menjadi tenang pada saat diperdengarkan } \\
\text { halhal } \\
\text { yang terkait dengan agama (misal: menyanyikan } \\
\text { lagu rohani, membacakan ayat-ayat kitab suci, } \\
\text { mengucapkan kata-kata bersyukur }\end{array}$ \\
\hline & $1-2$ tahun & $\begin{array}{l}\text { Mulai meniru ucapan maupun tindakan yang } \\
\text { terkait dengan ibadah agamanya }\end{array}$ \\
\hline & $2-3$ tahun & $\begin{array}{l}\text { Mulai meniru ucapan dan gerakan yang terkait } \\
\text { dengan ibadah agamanya }\end{array}$ \\
\hline & 3-4 tahun & Meniru ucapan dan melaksanakan ibadah \\
\hline & $4-5$ tahun & $\begin{array}{l}\text { Mulai mengucapkan doa-doa pendek dan } \\
\text { melakukan ibadah sesuai dengan agama yang }\end{array}$ \\
\hline
\end{tabular}




\begin{tabular}{|c|c|c|}
\hline Kompetensi Dasar & Usia & Indikator Pencapaian Perkembangan AUD \\
\hline & & dianutnya \\
\hline & \multirow[t]{5}{*}{$5-6$ tahun } & $\begin{array}{l}\text { Mengucapkan doa-doa pendek, melakukan } \\
\text { ibadah sesuai } \\
\text { dengan agamanya (misal: doa sebelum memulai } \\
\text { dan selesai kegiatan) }\end{array}$ \\
\hline & & $\begin{array}{l}\text { Berperilaku sesuai dengan ajaran agama yang } \\
\text { dianutnya (misal: tidak bohong, tidak berkelahi) }\end{array}$ \\
\hline & & Menyebutkan hari-hari besar agama \\
\hline & & Menyebutkan tempat ibadah agama lain \\
\hline & & $\begin{array}{l}\text { Menceritakan kembali tokoh-tokoh keagamaan } \\
\text { (misal: kisah nabi) }\end{array}$ \\
\hline
\end{tabular}

\section{SIMPULAN DAN SARAN}

Hasil penelitian ini memperoleh beberapa simpulan, yaitu: 1) Keberhasilan pembelajaran dalam CTL tidak diukur dari banyaknya materi akademis yang dihafalkan oleh peserta didik, melainkan adanya makna yang berhasil ditemukan. Semakin mampu mengaitkan materi akademis dengan konteks, peserta didik akan semakin banyak mendapatkan makna. Semakin banyak keterkaitan yang ditemukan siswa dalam suatu konteks yang luas, pembelajaran menjadi semakin bermakna bagi mereka. Kemampuan menguasai makna akan menuntun mereka untuk memahami pengetahuan dan keterampilan yang dipelajari. 2) Dengan demikian, keberhasilan pembelajaran pendidikan agama sejatinya bukan seberapa banyak doktrin dan dogma yang dihafalkan oleh peserta didik. Keberhasilan itu diukur dari kemampuan dalam menghubungkan materi agama dengan konteks kehidupan sehari-hari dan kemampuan memproduksi makna dari hubungan tersebut. Karena itulah Pendekatan CTL dapat menjadi alternatif dalam pencapaian perkembangan aspek agama pada PAUD agar terbebas dari indikasi pemahaman radikal dan intoleran dikarenakan. 3) Dalam batas-batas tertentu CTL dapat dilacak pada praktik pengajaran Islam yang dilakukan oleh Rasulullah saw untuk para sahabat. Saat itu praktik-

Implementasi Contextual Teaching and Learning dalam Pencapaian Perkembangan Aspek Agama pada Anak Usia Dini (Pendekatan Filsafat Ilmu-Ilmu Keislaman) Copyright (c) 2021 Armanila 
http://jurnaltarbiyah.uinsu.ac.id/index.php/raudhah

e-mail: jurnalraudhah@uinsu.ac.id

p-ISSN: 2338-2163

e-ISSN: $2716-2435$

praktik pembelajaran CTL seperti konstruktivisme, inquiry, modeling, learning community, maupun authentic assesment. 4) Pendekatan CTL dalam mencapai perkembangan aspek agama pada anak usia dini bisa diarahkan kepada sisi historisitas Islam. Historisitas Islam merupakan kajian yang bersifat fleksibel dan temporer. Historisitas Islam yang dapat dieksplorasi dalam pembelajaran berupa pengalaman keagamaan (religious experience), baik pengalaman diri sendiri maupun orang lain, baik yang sedang terjadi maupun yang sudah menyejarah. Karena itu peserta didik tidak perlu belajar doktrin dan dogma agama. 5) Pendekatan CTL bertujuan agar peserta didik dapat menemukan makna di balik materi yang dipelajari. Konteks makna tersebut dapat ditemukan pada dimensi kelima dari lima dimensi religius, yakni arti penting agama. Dengan demikian dapat dikatakan bahwa tujuan pendekatan CTL pada pencapaian perkembangan aspek agama pada anak usia dini adalah agar peserta didik dapat menemukan arti penting agama bagi diri mereka. Agar dapat menemukan arti penting agama, maka peserta didik harus menghubungkan materi pelajaran dengan kehidupan yang mereka hadapi dalam kehidupan sehari-hari atau yang disebut dengan religious experience atau pengalamaan keagamaan. Pencapaian perkembangan aspek agama pada anak usia dini tidak dilakukan dengan mengajarkan doktrin dan dogma, melainkan mengeksplorasi pengalaman keagamaan peserta didik. Bersumber dari pengalaman keagamaan ini, peserta didik dapat diarahkan untuk mengonstruksi pengetahuan mereka tentang keberagamaan yang bermakna bagi diri mereka.

\section{DAFTAR PUSTAKA}

Abdi, M. I. (2011). Contextual Teaching And Learning (CTL) Dalam Pembelajaran PAI. Dinamika Ilmu: Jurnal Pendidikan, 11(1).

Abdullah, M. A. (2002). Studi Agama; Normativitas atau Historisitas? Yogyakarta: Pustaka Pelajar.

Abdullah, M. A. (2012). Islamic Studies di Perguruan Tinggi; Pendekatan IntegratifInterkonektif. Yogyakarta: Pustaka Pelajar.

Al-Qur'an, L. P. M. (2014). Tafsir Al-Qur'an Tematik. Jakarta: Kamil Pustaka.

Alwasilah, A. C. (2008). Tujuh Ayat Pendidikan Kontekstual', in Contextual Teaching \& Learning: Menjadikan Kegiatan Belajar. Bandung: Mizan Learning Centre.

Implementasi Contextual Teaching and Learning dalam Pencapaian Perkembangan Aspek Agama pada Anak Usia Dini (Pendekatan Filsafat Ilmu-Ilmu Keislaman) Copyright (c) 2021 Armanila 
Hanafi, Y. (2017). Transformasi Kurikulum Mata Kuliah Pendidikan Agama Islam di Perguruan Tinggi Umum: Dari Paradigma Normatif-Doktriner Menuju Paradigma Historis-Kontekstual. Jurnal Pendidikan Dan Pembelajaran (JPP), 23(1).

Harudin, M. (2018). Penerapan Pendekatan Contextual Teaching And Learning (CTL) Dan Pembelajaran Berbasis Kearifan Lokal Untuk Meningkatkan Aktivitas Belajar Siswa Mata Pelajaran Pendidikan Agama Islam (Studi pada siswa kelas V SD Islam Terpadu Madani Kabupaten Aceh Tenggara. Attazakki: Jurnal Kajian Ilmu Pendidikan Islam Dan Humaniora, 2(1).

Johnson, E. B. (2008). Contextual Teaching \& Learning; Menjadikan Kegiatan BelajarMengajar Mengasyikkan dan Bermakna, trans. by Ibnu Setiawan. Bandung: Mizan Learning Centre.

Khotib, M. A. Al. (1981). Ushul al Hadith Ulumuhu Wamustholakuhu. Beirut: Dar al-Fikr.

Mahmud. (2011). Metode Penelitian Pendidikan. Bandung: Pustaka Setia.

Mestika, Z. (2008). Metode Penelitian Kepustakaan. Jakarta: Yayasan Obor Indonesia.

Pearce, L. D., Hayward, G. M., \& Pearlman, J. A. (2017). Measuring Five Dimensions of Religiosity Across Adolescence. Review of Religious Research, 59(3). 